\title{
Exploring Student Motivation and Performance in the Flipped Classroom: A Case Study of Nursing Students
}

\author{
Aziz Naciri ${ }^{1 *}$ (D), Mohamed El Hajji ${ }^{2}$ (D), Mohamed Radid ${ }^{3,4}$ (D), Ahmed Kharbach ${ }^{5,6}$ (D), Ghizlane Chemsi ${ }^{1,4}$ (D)
}

\author{
${ }^{1}$ Laboratory of Sciences and Technologies of Information and Education, Faculty of Sciences Ben M'Sik, Hassan II University of Casablanca, MOROCCO \\ ${ }^{2}$ Regional Center for Careers Education and Training, Agadir, MOROCCO \\ ${ }^{3}$ Laboratory of Physical Chemistry of Materials, Faculty of Sciences Ben M'Sik, Hassan II University of Casablanca, MOROCCO \\ ${ }^{4}$ Observatory of Research in Interdisciplinary Didactics and University Pedagogy, Faculty of Sciences Ben M'Sik, Hassan II University of Casablanca, Casablanca, \\ MOROCCO \\ ${ }^{5}$ Laboratory of Biostatistics, Clinical Research and Epidemiology, Faculty of Medicine and Pharmacy of Rabat, Mohamed V University, Rabat, MOROCCO \\ ${ }^{6}$ High Institute of Nursing Professions and Technical Health, Agadir, MOROCCO \\ *Corresponding Author: Aziz.naciri-etu@etu.univh2c.ma
}

Citation: Naciri A, El Hajji M, Radid M, Kharbach A, Chemsi G. Exploring Student Motivation and Performance in the Flipped Classroom: A Case Study of Nursing Students. Electron J Gen Med. 2022;19(3):em364. https://doi.org/10.29333/ejgm/11796

\section{ARTICLE INFO}

Received: 19 Dec. 2021

Accepted: 6 Feb. 2022

\begin{abstract}
Introduction \& Background: Technological progress has transformed all areas including the field of education and training. This has allowed us to take advantage of the functionalities offered by information and communication technologies to improve learning experiences. This research aims to explore the motivation and performance of nursing students in the flipped classroom compared to the traditional method.

Methods: This pre-experimental study was conducted on a single group pretest-posttest with twenty students using two distinct teaching methods (the traditional method and the flipped classroom) in the community health planning course. In pre-test and post-test, motivation and performance scores were calculated, respectively, from the motivated strategies for learning questionnaire and the results of the performance tests. Pretest and posttest scores were compared using the Wilcoxon signed-rank test.

Results: The findings showed that the motivation scores of all students $(n=20)$ were positively improved in the flipped classroom compared to the traditional method. Specifically, extrinsic goal orientation $(p=0.021)$, control beliefs ( $p=0.019)$, and self-efficacy for learning and performance $(p=0.016)$ were the motivational subcomponents that were significantly improved. However, intrinsic goal orientation $(p=0.055)$, task value $(p=0.866)$, and test anxiety $(p=0.6)$ did not show a statistically significant. On the other hand, student performance was significantly improved in the flipped classroom (14.4 \pm 2.57 vs. $17.7 \pm 1.28, p<0.001)$.
\end{abstract}

Conclusion: This innovative approach is an essential alternative for improving the quality of nursing education.

Keywords: computer-assisted instruction, distance education, nursing students, problem-based learning, performance

\section{INTRODUCTION}

The nursing education system is evolving to help nursing students acquire the necessary knowledge and skills for effective nursing practice [1]. Indeed, skills based on active learning and critical thinking enable the delivery of adequate and quality care [2]. However, the traditional teaching methods currently used in nursing education do not develop students' reflective thinking skills [3]. Digital technologies in education can replace a passive learning environment characterized by a direct transfer of knowledge (from the teacher to the learner) with a more interactive learning environment [4]. As a hybrid learning approach, the flipped classroom promotes active learning $[5,6]$. It is a teaching model in which learners receive course content outside the classroom (educational resources, educational video vignettes, and quizzes) through a learning platform. While, class time is focused on active learning approaches (problem-solving, application exercises, discussion activities, and team learning). This method has several advantages and some limitations. Students come to the classroom well prepared in a flipped classroom, with similar information and relevant knowledge ready to be applied. This process promotes active engagement in activities that encourage active learning [7]. These involve different levels of Bloom's taxonomy [8]. In addition, active participation in class activities increases students' level of motivation [9]. Although the flipped classroom method has many advantages, it presents some challenges that make it difficult to implement. First of all, the teacher must devote a lot of time and effort before the class, especially to preparing the teaching video vignettes [10]. Furthermore, this method leads to difficulties and resistance to the new expectations and responsibilities imposed on students [11]. Moreover, limited access to digital technologies and the Internet can impede their learning [12]. Similarly, students who are not motivated to attend classes outside of class may not benefit from in-class activities [13]. 
Table 1. The teaching-learning process adapted during this study

\begin{tabular}{lcc}
\hline Teaching method & Activities to be carried out outside the classroom & Classroom activities \\
\hline Traditional & Pre-reading of articles made available to students & Listening \\
& & Take notes \\
& Asking questions & Practical workshops \\
& Task-based learning & Drawing with flip chart \\
Flipped classroom & View instructional video capsules on Moodle & Case studies \\
& Respond to video and/or quiz worksheets posted online & Discussions \\
& Discussion in the forums & Problem solving \\
\hline
\end{tabular}

On the other hand, learning motivation is a crucial research topic in the student teaching-learning process. Learning motivation is defined as a state of the students relating their perceptions and conceptions to their environment and generating engagement and participation in an academic task [14]. There are several theories of motivation. The present research will be limited to the model of motivation from a socio-cognitive perspective because it is strongly indicated for studying motivation in a digital learning context. This sociocognitive approach emphasizes that academic motivation results from the interaction between learners' perceptions and expectations on the one hand and the different elements of their environment on the other hand [15]. The theoretical model selected for this research is Pintrich's expectations and value model [16]. Indeed, it is a robust model that synthesizes many research results, integrating the concepts of self-efficacy and intrinsic or extrinsic orientation of motivation. In our knowledge, there are no studies in Morocco that investigate the motivation and performance of nursing students during flipped learning. The study conducted among the trainee demonstrated the effectiveness of the said method and its ability to improve the performance of these learners [17]. Likewise, another study conducted at a Moroccan university reported that the flipped classroom significantly improved the learning of students with learning disabilities [18]. Indeed, the effect of the flipped classroom on student motivation and performance has been reported in several studies in different contexts. Some have indicated a positive effect on student motivation [19-21]. Others have justified its effect on student performance $[22,23]$. However, other research has noted that the method has no significant effect on student performance $[24,25]$. Therefore, this study aims to explore the motivational level and performance of nursing students in the flipped classroom compared to the traditional method.

\section{MATERIALS AND METHODS}

\section{Design}

The study design is pre-experimental based on a single group pretest-posttest. The main independent variable is the flipped classroom method, and the dependent variables are student motivation and performance. The course, entitled "Community Health Planning," was 20 hours in length and was divided into two sessions of 10 hours each. The first session was conducted in a traditional teacher-centered method. The flow of information between the teacher and the students was mainly one-way. The classroom was organized with desks/chairs arranged in rows facing the blackboard, and students had no explicit tasks to prepare for class. The second session of the course was delivered using the flipped classroom approach using the MOODLE educational platform. Students receive the lectures in online resources (usually interactive video vignettes) supported by quizzes and exercises. The released time in class is reserved for peer discussions and group projects, which will give meaning to the content put on the platform (Table 1).

\section{Sample}

The study was conducted among 20 students in the third year of the nursing program, option: Polyvalent nurse at the Higher Institute of Nursing Professions and Technical Health of Agadir, Morocco.

\section{Data Collection}

\section{Student motivation}

In this study, student motivation was measured using "the motivated strategies for learning questionnaire." It was developed from Pintrich's social-cognitive model. This instrument has been confirmed by several research studies [26, 27]. It consists of 31 items divided into six subscales: intrinsic goal orientation (4 items), extrinsic goal orientation (4 items), task value ( 6 items), control beliefs ( 4 items), self-efficacy for learning and performance ( 8 items), and test anxiety ( 5 items). A 7-point Likert scale was used for each item, ranging from "strongly agree" to "strongly disagree."

\section{Student performance}

The participants' level of performance was tested at the end of the implementation of each teaching method. Students took a test consisting of 07 questions (direct questions, MCQs, and open-ended questions). The questions in each test were designed to meet the pedagogical objectives of the course in terms of "memorization", "comprehension", and "application" of Bloom's taxonomy [28].

\section{Data Analysis}

For data analysis, we used IBM SPSS 25.0 and Excel 2016. Pretest and posttest scores were compared using the Wilcoxon signed-rank test. A p-value less than $<0.05$ was considered statistically significant.

\section{Ethical Considerations}

Written permission was obtained to conduct the study from the Higher Institute of Nursing Professions and Technical Health Agadir (N19-74). Written consent was obtained from all participants. 
Table 2. Characteristics of study participants

\begin{tabular}{lc}
\hline Variables & $\begin{array}{c}\text { Number of } \\
\text { participants(\%) }\end{array}$ \\
\hline Genre & $17(85 \%)$ \\
\hline Female & $3(15 \%)$ \\
\hline Male & $21.5( \pm 0.8)$ \\
\hline Age: Mean(Standard deviation) & $18(90 \%)$ \\
\hline Possession of a personal computer & $20(100 \%)$ \\
\hline Possession of a smartphone & $11(55 \%)$ \\
\hline Access to an internet connection & $5(25 \%)$ \\
\hline Always & $5(25 \%)$ \\
\hline Often & $0(0 \%)$ \\
\hline Sometimes & $0(0 \%)$ \\
\hline Never & $0(0 \%)$ \\
\hline Previous use of an educational platform &
\end{tabular}

Table 3. Differences in student motivational scores between traditional and flipped classrooms

\begin{tabular}{lccc}
\hline \multirow{2}{*}{ The measurement scale } & $\begin{array}{c}\text { Traditional } \\
\text { method }\end{array}$ & $\begin{array}{c}\text { Flipped } \\
\text { classroom }\end{array}$ & \multirow{2}{*}{ p-value } \\
\cline { 2 - 3 } & Mean(SD) & Mean(SD) & \\
\hline Total motivation & $\begin{array}{c}30.23 \\
5.04(0.33)\end{array}$ & $\begin{array}{c}32.81 \\
5.47(0.52)\end{array}$ & 0.046 \\
\hline Intrinsic goal orientation & $5.29(0.7)$ & $5.88(0.4)$ & 0.055 \\
\hline Extrinsic goal orientation & $5.04(1.06)$ & $5.8(0.63)$ & 0.021 \\
\hline Task value & $5.48(0.8)$ & $5.72(0.87)$ & 0.866 \\
\hline Control beliefs & $5.28(0.72)$ & $5.95(0.02)$ & 0.019 \\
\hline $\begin{array}{l}\text { Self-efficacy for learning \& } \\
\text { performance }\end{array}$ & $5.10(0.7)$ & $5.54(0.54)$ & 0.016 \\
\hline Test anxiety & $4.05(1.07)$ & $3.92(0.6)$ & 0.600 \\
\hline
\end{tabular}

\section{RESULTS}

\section{Participants}

Out of 20 students, $85 \%$ were female, and the mean age was 21.5 years $(S D \pm 0.80)$. All participants owned a smartphone, and $94.4 \%$ reported having a personal computer. The majority of students (55\%) had constant access to an internet connection. However, all students (100\%) expressed a lack of knowledge of educational platforms and reported never having used them (Table 2 ).

\section{Student Motivation}

Students' motivation was assessed at the end of the traditional method and the flipped classroom. The results showed that students had a higher level of motivation in the flipped classroom than in the traditional method (5.04 $\pm 0.33 \mathrm{vs}$. $5.47 \pm 0.52, p<0.05)$. Also, the motivational subcomponents that were significantly improved in the posttest were: extrinsic goal orientation $(p=0.021)$, control beliefs $(p=0.019)$, and selfefficacy for learning and performance $(p=0.016)$. However, no significant difference was found for intrinsic goal orientation $(p=0.055)$, task value $(p=0.866)$, and test anxiety $(p=0.6)($ Table 3).

\section{Student Performance}

We assessed student learning outcomes after each instructional method. The results show that $95 \%$ of the students $(n=19)$ achieved higher flipped classroom scores than the traditional method (Figure 1). In addition, a significant

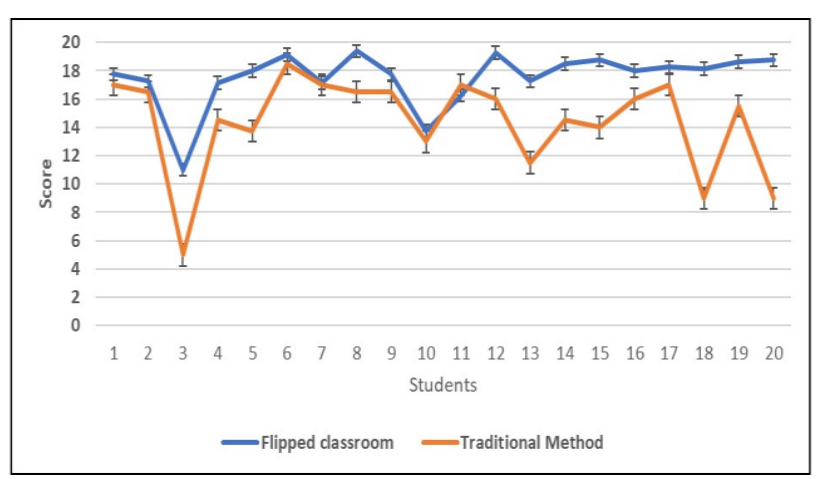

Figure 1. Comparisons of nursing student scores in the flipped classroom and the traditional method

Table 4. Comparisons of nursing students' grades in the flipped classroom and the traditional method

\begin{tabular}{llll}
\hline & $\begin{array}{c}\text { Traditional } \\
\text { method }\end{array}$ & $\begin{array}{c}\text { Flipped } \\
\text { classroom }\end{array}$ & p-value \\
\cline { 2 - 3 } & Mean(SD) & Mean(SD) & \\
\hline $\begin{array}{l}\text { Academic performance } \\
\text { of the group class }\end{array}$ & $14.4(2.57)$ & $17.7(1.28)$ & $<0.001$ \\
\hline
\end{tabular}

difference in total class performance was found in the flipped classroom (17.7 \pm 1.28$)$ vs. $(14.4 \pm 2.57)$ for the traditional method $(p<0.0001)$ (Table 4).

\section{DISCUSSION}

This study aims to explore nursing students' motivation and performance in the flipped classroom. The results suggest that student motivation improved significantly during flipped teaching $(p<0.05)$. These results are similar to studies $[9,19,29]$. The increase in student motivation scores in the flipped classroom has been explained differently in several contexts. The improvement in nursing students' motivation in the flipped classroom is due in part to the equitable, accessible, and repeated access to online educational resources, and in part to the respect for each student's learning pace [9]. The flexible learning environment supported by the flipped classroom also contributes to student motivation [20]. Furthermore, the increase in motivation was caused by various learning strategies such as critical thinking, task value, and peer learning [30].

Regarding motivational aspects in our research, the flipped classroom has a positive effect on three key components. The first is related to extrinsic goal orientation, in which students value academic success and approval from others $(p=0.021)$. This result could be linked to the learning activities proposed in the platform in the form of diversified exercises (worksheets of the video capsule, quiz in the form of multiple-choice questions, and open-ended questions), creating a feeling of rivalry and competitiveness within the class group (having a good grade, a satisfactory ranking within the class). As for the second motivational aspect, control beliefs showed a significant improvement $(p=0.019)$. Students believe that their academic performance is directly related to their efforts. This is probably due to the paradigm shift in the learning process. Since, in the flipped classroom, students are actively involved in the construction of their knowledge. Regarding the third component called self-efficacy for learning and performance, the post-test result is significantly improved $(p=0.016)$. In this 
motivational line, learners believe in their ability to adapt and control the behaviors necessary to achieve the required performance. This perception could be generated and consolidated by the flexible and supple learning environment, where freedom of expression and capitalization of learning through workshops meet the set learning objectives.

The present study recorded a significant improvement in student performance while switching from the transmissive to the flipped teaching approach $(p<0.001)$. This is consistent with the results of several studies in different settings $[22,23]$. The increase in performance was inherent in providing students with online video vignettes while allowing them to better assimilate the course before coming to class. As a result, the time freed up in class allows low-performing students to spend more time on practice exercises and correcting poorly learned sequences [23]. Moreover, another investigation [22], conducted at a medical university in China, found that improved student performance in flipped classrooms was strongly related to the intensification and diversification of classroom teaching-learning activities, with teachers having more time in class to facilitate discussions and answer quizzes rather than repeat rote didactics. In the present study, the improvement in the students' grade scores in the flipped classroom could be due, on the one hand, to intrinsic reasons related to the feeling of curiosity that immersion in this innovative teaching practice provokes. On the other hand, it could be due to the pedagogical video vignettes offered in the out-of-class platform. Furthermore, although an increase in motivation and performance was observed in students in the flipped classroom compared to the traditional classroom, this research did not identify the increase in motivation. However, previous studies have suggested a positive correlation between motivation and performance, indicating that there is also an improvement in academic performance when an increase in motivation is observed [31].

\section{Limitation of the Study}

This study has several limitations. First, we used a onegroup pre-test-post-test design, so our data are limited in causal inference. Second, only 10 hours of a course were flipped. This time seems insufficient to assess nursing students' motivation and performance. Third, the study was based on a cohort of students from a single institution with a specific course. Student motivation and performance may differ from one institution to another, from one course to another.

\section{CONCLUSION}

The findings of this study showed that student nurses' motivation was improved by switching from the traditional method to the flipped classroom. Motivation subcomponents such as extrinsic goal orientation, control beliefs, and selfefficacy for learning and performance showed statistically significant improvement in the posttest. Furthermore, student performance in the flipped classroom method showed a statistically significant improvement over the traditional method. Future research is needed to investigate the factors influencing student motivation and performance in the flipped classroom.

Author contributions: AN, AK, \& ME: conception and design, data analysis and interpretation; AN \& MR: manuscript draft; ME, MR, \& GC: critical revision of the manuscript; GC: final approval of the manuscript. All authors have agreed with the results and conclusions.

Funding: No funding source is reported for this study.

Acknowledgements: All authors would like to thank all the student nurses who participated in the study.

Declaration of interest: No conflict of interest is declared by authors.

\section{REFERENCES}

1. World Health Organization. Nurse educator core competencies. 2017. Available at: https://www.who.int/ hrh/nursing_midwifery/nurse_educator050416.pdf

2. Popil I. Promotion of critical thinking by using case studies as teaching method. Nurse Educ Today. 2011;31(2):204-7. https://doi.org/10.1016/j.nedt.2010.06.002 PMid:20655632

3. $\mathrm{Pu} \mathrm{D}, \mathrm{Ni}$ J, Song $\mathrm{D}$, et al. Influence of critical thinking disposition on the learning efficiency of problem-based learning in undergraduate medical students. BMC Med Educ. 2019;19(1):1-8. https://doi.org/10.1186/s12909-0181418-5 PMid:30606170 PMCid:PMC6318932

4. Bransford J, Brophy S, Williams S. When computer technologies meet the learning sciences: Issues and opportunities. J Appl Dev Psychol. 2000;21(1):59-84. https://doi.org/10.1016/S0193-3973(99)00051-9

5. Galway LP, Corbett KK, Takaro TK, Tairyan K, Frank E. A novel integration of online and flipped classroom instructional models in public health higher education. BMC Med Educ. 2014;14(1):1-9. https://doi.org/10.1186/ 1472-6920-14-181 PMid:25169853 PMCid:PMC4167261

6. Roehl A, Reddy SL, Shannon GJ. The flipped classroom: An opportunity to engage millennial students through active learning strategies. J Fam Consum Sci. 2013;105(2):44-9. https://doi.org/10.14307/JFCS105.2.12

7. McLaughlin JE, Roth MT, Glatt DM, et al. The flipped classroom: A course redesign to foster learning and engagement in a health professions school. Acad Med. 2014;89(2):236-43. https://doi.org/10.1097/ACM. 0000000000000086 PMid:24270916

8. Lebrun M. Essai de modélisation et de systémisation du concept de classes inversées [Modeling and systemization of the concept of flipped classrooms]. 2016. Available at: http://lebrunremy.be/WordPress/?p=740

9. Davey P. The flipped classroom: Motivating student nurses to learn independently. Athens J Health. 2015;2(4):261-70. https://doi.org/10.30958/ajh.2-4-2

10. Mazur A, Brown B, Jacobsen M. Learning designs using flipped classroom instruction (Conception d'apprentissage à l'aide de l'instruction en classe inverse). Can J Learn Technol. 2015;41(2). https://doi.org/10.21432/T2PG7P

11. Bland L. Applying flip/inverted classroom model in electrical engineering to establish life long learning [Paper presentation]. 2006 Annual Conference \& Exposition. Chicago, IL. https://doi.org/10.18260/1-2--491

12. Lane-Kelso $M$. The pedagogy of flipped instruction in Oman. Turkish Online J Educ Technol. 2015;14(1):143-50.

13. Bergmann J, Sams A, Nizet I, Bernard S, Piette W. La classe inverse [The flipped classroom]. Les Éditions Reynald Goulet, Inc.; 2014.

14. Bégin C, Barbeau D. Interventions pédagogiques et réussite au cégep: Méta-analyse [Pedagogical interventions and success in cegep: Meta-analysis]. Revue des sciences de l'éducation [J Educ Sci.]. 2010;36(1):268-9. https://doi.org/ 10.7202/043997ar 
15. Pintrich PR, Schunk DH. Motivation in education: Theory, research, and applications. 2nd ed. Upper Saddle River, NJ: Prentice Hall; 2002.

16. Pintrich PR. Motivation and classroom learning. In: Reynolds WM, Miller GE, editors. Handbook of psychology: Educational psychology, Vol. 7. John Wiley \& Sons Inc.; 2003. p. 103-22. https://doi.org/10.1002/0471264385. wei0706

17. El Hajji M, Bouzaidi E, Drissi R, Douzi H, Khouya EH. New blended learning strategy based on flipped-learning for vocational work-linked training. J Educ Pract. 2016;7(36):126-30.

18. Abdelaziz AMA. An experience in Moroccan university using flipped classroom method. International Conference on Information and Communication Technologies for Education and Training and International Conference on Computing in Arabic (ICCA-TICET). IEEE; 2017. https://doi.org/10.1109/ICCA-TICET42244.2017

19. Chung EJ, Lee B-H. The effects of flipped learning on learning motivation and attitudes in a class of college physical therapy students. J Probl-based Learn. 2018;5(1):29-36. https://doi.org/10.24313/jpbl.2018.5.1.29

20. Díaz-Garrido E, Luz Martín-Peña M, María Sánchez-López J. El impacto del flipped classroom en la motivación y en el aprendizaje de los estudiantes en la asignatura dirección de operaciones [The impact of the flipped classroom on the motivation and learning of students in the subject operations management]. Work Pap Oper Manag. 2017;8. https://doi.org/10.4995/wpom.v8i0.7091

21. Yilmaz R. Exploring the role of e-learning readiness on student satisfaction and motivation in flipped classroom. Comput Hum Behav. 2017;70:251-60. https://doi.org/ 10.1016/j.chb.2016.12.085

22. Cheng $X$, Lee KKH, Chang EY, Yang X. The "flipped classroom" approach: Stimulating positive learning attitudes and improving mastery of histology among medical students. Anat Sci Educn. 2017;10(4):317-27. https://doi.org/10.1002/ase.1664 PMid:28199052
23. Cormier C, Voisard B. Flipped classroom in organic chemistry has significant effect on students' grades. Front ICT. 2018;4:30. https://doi.org/10.3389/fict.2017.00030

24. Clark RM, Besterfield-Sacre M, Budny D, et al. Flipping engineering courses: A school wide initiative. Adv Eng Educ. 2016;5(3):n3.

25. Zuber WJ. The flipped classroom, a review of the literature. Ind Commer Train. 2016. https://doi.org/10.1108/ICT-052015-0039

26. Berger J-L, Karabenick SA. Motivation and students' use of learning strategies: Evidence of unidirectional effects in mathematics classrooms. Learn Instr. 2011;21(3):416-28. https://doi.org/10.1016/j.learninstruc.2010.06.002

27. Nie Y, Lau S. Differential relations of constructivist and didactic instruction to students' cognition, motivation, and achievement. Learn Instr. 2010;20(5):411-23. https://doi.org/10.1016/j.learninstruc.2009.04.002

28. Bloom BS. Taxonomy of educational objectives. Vol. 1: Cognitive domain. New York: McKay; 1956.

29. Xin-Yue Z. Motivation in a flipped classroom, a case study of teaching oral English in a vocational college in Mainland China. Sino-US English Teach. 2016;13(6):460-7. https://doi.org/10.17265/1539-8072/2016.06.004

30. Van Vliet EA, Winnips JC, Brouwer N. Flipped-class pedagogy enhances student metacognition and collaborative-learning strategies in higher education but effect does not persist. Life Sci Educ. 2015;14(3):ar26. https://doi.org/10.1187/cbe.14-09-0141 PMid:26113628 PMCid:PMC4710384

31. Bryan RR, Glynn SM, Kittleson JM. Motivation, achievement, and advanced placement intent of high school students learning science. Sci Educ. 2011;95(6):1049-65. https://doi.org/10.1002/sce.20462 